\title{
Evaluation of ethanolic extracts of Piper guineense, Dennettia tripetala, and Capsicum frutescens as protectant of smoked fish, Clarias gariepinus (Pisces: Clariidea) against Dermestes maculatus (Coleoptera: Dermestidae)
}

Tejumade Mary Philip-Attah(1)

\begin{abstract}
Background: Dermestes maculatus is a destructive pest of smoked-dried fish. Due to its implications, this research was aimed at investigating the insecticidal activities of edible plant extracts on smoked Clarias gariepinus as protectants against Dermestes maculatus.

Result: The extract of Piper guineense at 4\%, 8\%, and 12\% concentrations recorded between 8-92\% and 33-100\% mortalities, respectively, for the first 4 weeks and $0 \%$ mortality was observed in weeks 5-8. The extracts of Capsicum frutescens and Dennettia tripetala at 4\% concentration recorded between 8 and 92\% mortalities in the first 4 weeks and 5 weeks, respectively, and no mortality was recorded in the remaining weeks. At 12\% concentration for Dennettia tripetala extract, 8-100\% mortality was recorded throughout the experimental period. At $12 \%$ concentration for Capsicum frutescens, 8-92\% mortality was recorded in weeks 1-7 and 0\% in week 8. Positive control recorded 33-67\% mortality in weeks $1-4$ and $0 \%$ mortality in weeks $5-8$. Negative control recorded no mortality in the first 3 weeks, but few larvae were found dead in the remaining weeks. The mean value of 106, 36, and 96 progenies emerged at 4\%, 8\%, and $12 \%$ concentrations, respectively, in the smoked fish treated with Piper guineense. Mean value of 0.50 and 0.50 progenies were recorded at $4 \%$ and $8 \%$ concentrations, respectively, while no emergence was observed at $12 \%$ concentration of Dennettia tripetala extract. Extract of Capsicum frutescens recorded mean value of 1.00, 3.00, and 3.50 progenies at $4 \%, 8 \%$, and $12 \%$ concentrations, respectively. Weight loss of $66.47 \%, 31.46 \%$, and $56.25 \%$ at $4 \%, 8 \%$, and $12 \%$ concentrations was observed for Piper guineense extract respectively. Extracts of Dennettia tripetala and Capsicum frutescens recorded weight loss of $3.46 \%, 2.11 \%$, and $0.02 \%$ and $27.77 \%, 12.30 \%$, and $22.90 \%$, respectively, at $4 \%, 8 \%$, and $12 \%$ concentrations. Positive and negative controls recorded $4.36 \%$ and $81.18 \%$ weight loss, respectively.

Conclusion: They can therefore serve as affordable substitutes for synthetic chemicals which had been proven to be detrimental to the health of its consumers.
\end{abstract}

Keywords: Piper guineense, Dennettia tripetala, Capsicum frutescens, Dermestes maculatus, Clarias gariepinus

Correspondence: tmadenoni@gmail.com

Department of Zoology, University of Ibadan, Ibadan, Nigeria 


\section{Background}

The fish beetle, Dermestes maculatus (Coleoptera; Dermestidae), is one of the most destructive pests of stored smoked-dried fish in Nigeria. Johnson and Esser (2000) reported that it accounts for about 71.5\% losses in both quality and quantity of smoked fish. Dermestes maculatus proliferates and feeds on the flesh of smoked fish, thereby changing its appearance, making it unfit for consumption and marketing (Food and Agriculture Organization, 1981).

Due to the economic loss and mental torture procured by fish mongers, the use of synthetic chemicals has been employed to protect their stock from insect infestation for lack of credible alternatives. Many synthetic chemicals such as pentachlorophenol (PCPs), polychlorinated biphenyls (PCBs), atrasine (S-triazines), organochlorines (OCs), organophosphates (Ops), and carbamates are no doubt effective against the pests of treated smoked fish, but some attendant problems such as insecticide resistance, lack of technical-know-how, high cost of purchase, and mammalian toxicity are better imagined than real.

These reasons have brought to fore the need to seek alternative method(s) of controlling insect infestation on smoked fish, and one of these is the use of plant-based insecticides which are eco-friendly and safe for consumption as well as having insecticidal properties.

Prior to this time, some studies had been carried out by renowned researchers to vindicate the use of botanical insecticides as safe and reliable alternative to curb pest menace on stored products Akinbuluma, Adepetun, and Yeye (2015); Akinwumi (2011); Anyaele and Amusan (2003); Echezona (2006); Echo, Osuagwu, Agbor, Okpako, and Ekanem (2012); Olayinka-Olagunju (2014), and Owoade (2008); and Sowumi (2007).

Therefore, the aim of this study which was to evaluate the efficacy of ethanolic plant extracts of Piper guineense, Dennettia tripetala, and Capsicum frutescens as possible protectant of smoked fish (Clarias gariepinus) against Dermestes maculatus infestation was achieved though the following objectives:

- Determine the level of mortality caused by each extract on the test smoked-dried fish at different concentrations.

- Examine the reproductive performance of the beetles on treated smoked $C$. gariepinus.

- Determine the level of damage done on the test smoked-dried fish.

\section{Materials and methods}

The research was carried out in the Advance Research Entomology Laboratory of the Department of Zoology $\left(7.44^{\circ} \mathrm{N}, 3.93^{\circ} \mathrm{E}\right)$, University of Ibadan Oyo-State, from the month of July-October, 2015 , at $27 \pm 5^{\circ} \mathrm{C}$ and $82 \pm$ $5 \%$ temperature and relative humidity, respectively.

\section{Preparation of plant extracts}

Fresh fruits of Dennettia tripetala (pepper fruit), Capsium frutescens (bird pepper), and Piper guineense (black pepper) were purchased from a local herbal store at Moferere market in Ondo town, Ondo state, Nigeria. Each of the plant samples was air-dried in the laboratory because the active ingredients which may be thermolabile or volatile and ground into fine powder. The extraction process was carried out in the Advance Research Entomology Laboratory of the Department of Zoology, University of Ibadan, where 400 $\mathrm{g}$ of each pulverized parts were subjected to cold extraction method so as to avoid denaturing of the active ingredients by soaking in $99 \%$ analytical grade of ethanol for $72 \mathrm{~h}$ and stirred every $24 \mathrm{~h}$ to ensure proper dissolution of the active ingredients. After 72 $\mathrm{h}$, the filtrate was gotten using Whatsmann no. 1 filter paper which was taken to the Organic Chemistry Laboratory of the Department of Pharmaceutical Chemistry, University of Ibadan, for concentration using rotary evaporator at $40{ }^{\circ} \mathrm{C}$.

\section{Collection and maintenance of test insect}

The initial source of culture was obtained from infested smoked Clarias gariepinus collected from a dried fish market in Ondo town, Nigeria, and acclimatized for 30 days. The culture was maintained separately in a kliner jars covered with muslin cloth under laboratory condition and kept at temperature $25 \pm 5^{\circ} \mathrm{C}$ and relative humidity $80 \pm 5 \%$ at the Advance Research Entomology Laboratory in the Department of Zoology, University of Ibadan, Nigeria, for a month as being described by Akinwumi et al. (2006). New generations were prepared by removing the beetles from the stock culture, into a fresh uninfested fish, then removing the parent adults after 2-3 weeks oviposition period. Water was supplied with pieces of soaked cotton wool in order to induce oviposition.

\section{Collection and preparation of fish samples}

Samples of African mud catfish Clarias gariepinus were bought from Bodija market, Ibadan, Oyo state, which was later taken to the General Research Laboratory to disinfect by heat making use of Gallenkamp oven at $60{ }^{\circ} \mathrm{C}$ for $60 \mathrm{~min}$ and was later air-dried to prevent mold growth (Adedire \& Lajide, 2000), and $25-36 \mathrm{~g}$ of the disinfected fish sample was weighed into different jars. 
Effects of plant extracts on larvae of $D$. maculatus

Three different nominal concentrations namely $0.4 \mathrm{ml}$, $0.8 \mathrm{ml}$, and $1.2 \mathrm{ml}$ of Dennettia tripetala, Capsium frutescens, and Piper guineense ethanolic extracts corresponding to $4 \%, 8 \%$, and $12 \%$ were used. The concentrations were applied separately in $9.6 \mathrm{ml}, 9.2 \mathrm{ml}$, and $8.8 \mathrm{ml}$ of analytical grade of ethanol to make up $10 \mathrm{ml}$ of the concentration which was thoroughly rubbed using Camel brush on the disinfected dried fish (Clarias gariepinus) in each separate plastic container. The treated fish samples were exposed to dryness for $2 \mathrm{~h}$ to remove traces of the solvent.

Six unsexed 4th instar larvae of $D$. maculatus were introduced into each container containing different concentrations of the extracts and covered with muslin cloth held tightly in place with rubber bands to provide aeration and prevent entry/escape of insects which was kept under ambient laboratory conditions of $27 \pm 5{ }^{\circ} \mathrm{C}$ and $82 \pm 5 \%$ R.H. In like manner, vegetable oil was mixed thoroughly with each plant extracts at different concentrations of $4 \%, 8 \%$, and $12 \%$ and the set up was done as the above. Two control treatments were set up: one was treated with only vegetable oil and the other was without any treatment. Two replicates of the treatments and controls (treated and untreated) were laid out in completely randomized design (CRD). Dead larvae were replaced to make up the total number of insects introduced initially after every 7 days, and mortality counts were taken for 60 days. Weight loss was measured by re-weighing the fish after 90 days of treatment to assess the level of damage done. Percentage weight loss was calculated by dividing the difference over the initial weight multiplied by 100 .

$$
\% \text { weight loss }=\frac{\text { intial weight-final weight }}{\text { intial weight }} \times \frac{100}{1}
$$

\section{Statistical analysis}

Data were subjected to analysis of variance using IBM SPSS Statistics version 20, and where significant differences existed, treatment means were compared at 0.05 significant level using Tukey's test.

\section{Results}

Effects of ethanolic extracts of $P$. guineense against Dermestes maculatus larvae

The pesticidal effects of the ethanolic extract of $P$. guineense on the mortality of $D$. maculatus larvae are shown in Fig. 1. At $4 \%$ concentration, highest mortality of $92 \%$ in week 1 decreases to $8 \%$ in week 4 and no mortality was observed in week $8\left(p^{<} 0.05\right)$. At $8 \%$ concentration, highest mortality of $92 \%$ was recorded in week 1 which reduces to $50 \%$ in week 2 and $0 \%$ in week 8 , $(p<0.05)$. At $12 \%$ concentration, highest mortality of $100 \%$ in week 1 which decreases to $33 \%$ in week 4 and no mortality in week 8 was recorded $\left(p^{<} 0.05\right)$. The positive control recorded $67 \%$ mortality in week $1,33 \%$ in week 4 , and $0 \%$ in week 8 . The negative control recorded no mortality in the first 3 weeks although few larvae died in the later week.

Furthermore, Table 1 shows the progeny production and weight loss in different concentration of fish treated with extract of Piper guineense. The extract exhibited highest progeny production of 106 at 4\% treatment concentration and lowest production of 36 at $8 \%$

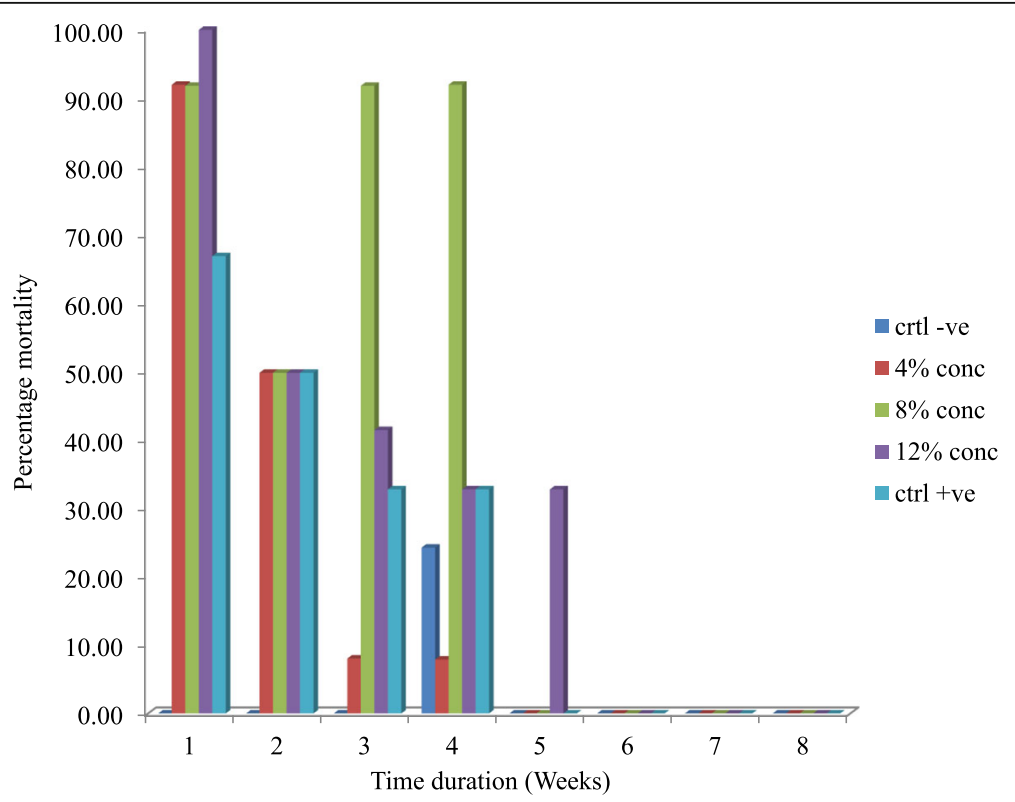

Fig. 1 Pesticidal effect of ethanolic extract of Piper guineense 
Table 1 Pesticidal effect of ethanolic extract of $P$. guineense on emergence and weight loss

\begin{tabular}{llll}
\hline Plant extract & Concentration (\%) & $\begin{array}{l}\text { Weight loss (\%) } \\
\text { Mean } \pm \text { SE }\end{array}$ & $\begin{array}{l}\text { Emergence } \\
\text { Mean } \pm \text { SE }\end{array}$ \\
\hline Piper guineense & 4 & $66.47 \pm 2.07 \mathrm{~b}$ & $106 \pm 4.00 \mathrm{a}$ \\
& 8 & $31.46 \pm 18.20 \mathrm{c}$ & $36 \pm 34.00 \mathrm{~b}$ \\
& 12 & $56.25 \pm 8.68 \mathrm{ab}$ & $96 \pm 1.00 \mathrm{a}$ \\
Positive control & 0 & $4.36 \pm 1.72 \mathrm{~d}$ & $3.50 \pm 1.50 \mathrm{c}$ \\
Negative control & 0 & $81.18 \pm 1.15 \mathrm{a}$ & $110.00 \pm 10.00 \mathrm{a}$
\end{tabular}

Means with different superscripts in each column are significantly different $\left(p^{<} 0.05\right)$ by Tukey's test

concentration. However, in the control set ups, positive control had 3.50 on the average while negative control recorded 110 progenies $(p<0.05)$. The highest weight loss of $66.47 \%$ at $4 \%$ treatment concentration and lowest weight loss of $56.25 \%$ at $8 \%$ concentration was observed $(p<0.05)$. In the control set up, positive control at all treatment concentrations recorded a weight loss of $4.36 \%$ while the negative control had $81.18 \%$ weight loss.

\section{Effects of ethanolic extracts of Dennettia tripetala against Dermestes maculatus larvae}

Results on mortality of $D$. maculatus in smoked fish treated with ethanolic extract of $D$. tripetala are presented in Fig. 2. At 4\% concentration, highest mortality of $100 \%$ in week 1 decreases to $50 \%$ in week 4 and no mortality was observed in week $8(p<0.05)$. At $8 \%$ concentration, mortality of $100 \%$ was recorded in week 1 which reduces to $8 \%$ in week 7 and $0 \%$ in week 8 , $(p<0.05)$. At $12 \%$ concentration, highest mortality of $100 \%$ in week 1 which decreases to $24.50 \%$ in week 7 and $8 \%$ in week 8 was recorded $(p<0.05)$. The positive control recorded $67 \%$ mortality in week $1,33 \%$ in week 4 , and $0 \%$ in week 8 . The negative control recorded no mortality in the first 3 weeks although few larvae died in the later week.

Also Table 2 shows the progeny production and weight loss in different concentration of fish treated with extract of Dennettia tripetala. The effect of $D$. tripetala extract produced 0.50 on the average as the highest number of progenies at $4 \%$ and lowest number of emergence of 0 at $12 \%$ treatment concentration $(p>0.05)$, compared to both positive and negative controls which produced 3.50 and 110 progenies, respectively. Highest weight loss of $3.46 \%$ at $4 \%$ treatment concentration and lowest weight loss of $0.02 \%$ at $12 \%$ treatment concentration was recorded $(p<0.05)$. In the control set up, positive control had $4.36 \%$ while the negative control recorded $81.18 \%$ weight loss.

\section{Effects of ethanolic extracts of Capsicum frutescens against Dermestes maculatus larvae}

Results on mortality of $D$. maculatus in smoked fish treated with ethanolic extract of $C$. frutescens are presented in Fig. 3. At $4 \%$ concentration, highest mortality of $92 \%$ in week 1 which decreases to $8 \%$ in week 5 and no mortality was observed in week 8 was observed $(p<0.05)$. At $8 \%$ concentration, mortality of $100 \%$ was recorded in week 1 which reduces to $41.50 \%$ in week 4

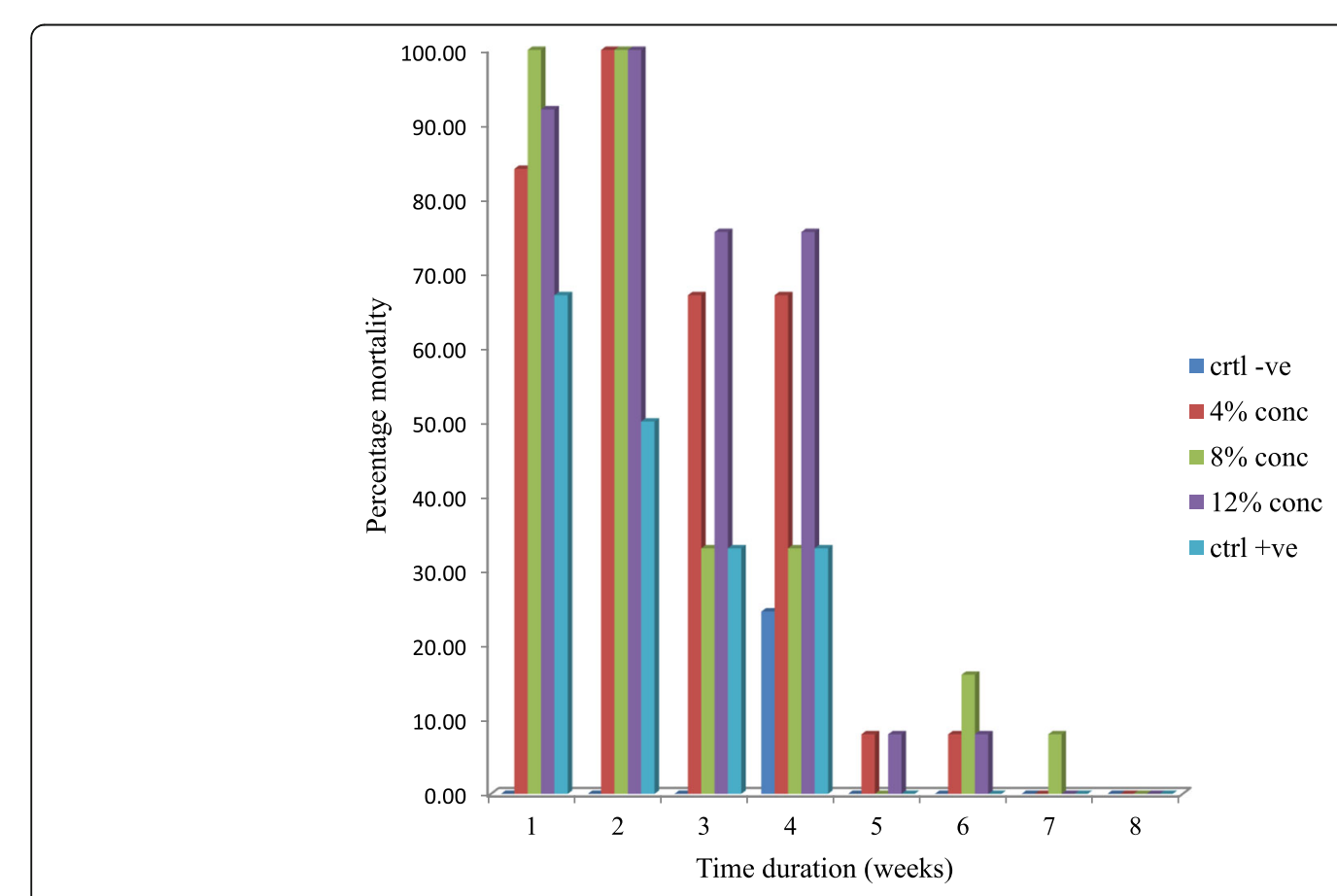

Fig. 2 Pesticidal effect of ethanolic extract of Dennettia tripetala 
Table 2 Pesticidal effect of ethanolic extract of D. tripetala on emergence and weight loss

\begin{tabular}{llll}
\hline Plant extract & Concentration (\%) & $\begin{array}{l}\text { Emergence } \\
\text { Mean } \pm \text { SE }\end{array}$ & $\begin{array}{l}\text { Weight loss (\%) } \\
\text { Mean } \pm \text { SE }\end{array}$ \\
\hline Dennettia tripetala & 4 & $0.50 \pm 0.50 \mathrm{a}$ & $3.46 \pm 3.46 \mathrm{a}$ \\
& 8 & $0.50 \pm 0.50 \mathrm{a}$ & $2.11 \pm 2.11 \mathrm{a}$ \\
& 12 & $0.00 \pm 0.00 \mathrm{a}$ & $0.02 \pm 0.02 \mathrm{~b}$ \\
Positive control & 0 & $3.50 \pm 1.50 \mathrm{~b}$ & $4.36 \pm 1.72 \mathrm{a}$ \\
Negative control & 0 & $110.00 \pm 10.00 \mathrm{c}$ & $81.18 \pm 1.15 \mathrm{c}$ \\
\hline
\end{tabular}

Means with different superscripts in each column are significantly different $\left(p^{<} 0.05\right)$ by Tukey's test

and $0 \%$ in week $8,(p<0.05)$. At $12 \%$ concentration, highest mortality of $92 \%$ in week 1 which decreases to $8 \%$ in week 7 and $0 \%$ in week 8 was recorded $\left(p^{<} 0.05\right)$. The positive control recorded $67 \%$ mortality in week 1 , $33 \%$ in week 4 , and $0 \%$ in week 8 . The negative control recorded no mortality in the first 3 weeks although few larvae died in the later week.

In addition, Table 3 shows the progeny production and weight loss in different concentrations of fish treated with extract of $C$. frutescens highest progeny emergence of 3.50 on the average at $12 \%$ treatment concentration and lowest emergence of 1.00 at $4 \%$ concentration $(p>$ 0.05 ) was observed, compared to both positive and negative controls that produced 3.50 and 110 progenies, respectively. The highest weight loss of $26.77 \%$ was recorded at $4 \%$ treatment concentration, and the lowest weight loss of $12.30 \%$ at $8 \%$ concentration $(p<0.05)$. In the control set up, positive control (vegetable oil) recorded a weight loss of $4.36 \%$, while negative control had $81.18 \%$.weight loss.

\section{Discussion}

The study compared the efficacies of ethanolic extracts of Piper guineense, Dennettia tripetala, and Capsicum frutescens as protectants against the insect-pest of fish, Dermestes maculatus on smoked catfish, Clarias gariepinus. The result showed varying degree of pesticidal activities. Extract of $P$. guineense recorded highest mortality of $100 \%$ at $12 \%$ concentration in week 1 , and then, the potency decreases with time up to week 4 until no sign of mortality was seen. Whereas at $8 \%$ concentration of the extract, there was sustained protection up to the first 4 weeks until no significant mortality was recorded after week 4 . The emergence of numerous progenies of $D$. maculatus on fish treated with $P$. guineense suggested that the extract was no longer effective in the outright killing of the larvae due to the deterioration in the potency of the extract, thereby resulting in significant weight loss of the smoked fish at the end of 90 days post treatment compared to the negative control. However, the extract of $D$. tripetala recorded $100 \%$ mortality at all concentrations in the first week, and $12 \%$ treatment concentration protected the smoked fish longer even though the potency reduces with the length of storage. There was negligible number of progeny emergence recorded both $4 \%$ and $8 \%$ and significant reduction in weight loss at the end of 90 days compared to the negative control. Likewise, the extract of $C$. frutescens

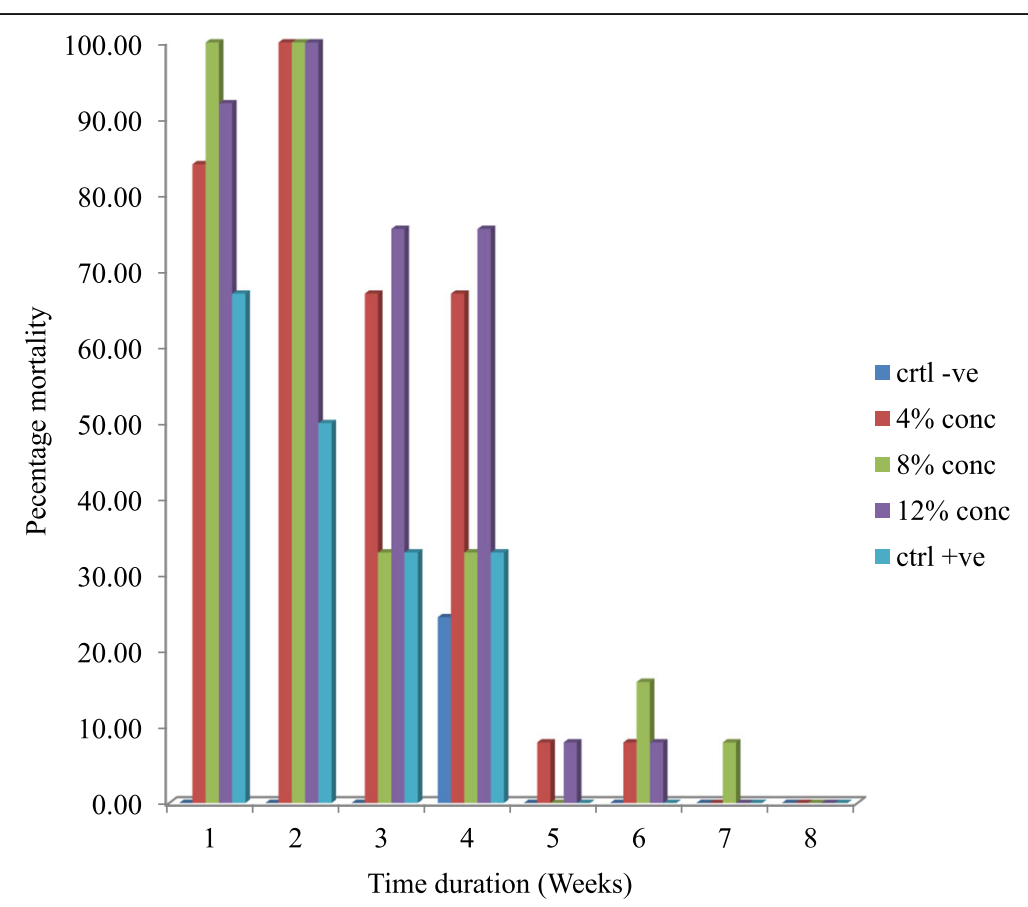

Fig. 3 Pesticidal effect of ethanolic extract of Capsicum frutescens 
Table 3 Pesticidal effect of ethanolic extract of $C$. frutescens on emergence and weight loss

\begin{tabular}{llll}
\hline Plant extract & Concentration (\%) & $\begin{array}{l}\text { Emergence } \\
\text { Mean } \pm \text { SE }\end{array}$ & $\begin{array}{l}\text { Weight loss (\%) } \\
\text { Mean } \pm \text { SE }\end{array}$ \\
\hline Capsicum & 4 & $1.00 \pm 1.00 \mathrm{a}$ & $26.77 \pm 21.20 \mathrm{a}$ \\
frutescens & 8 & $3.00 \pm 1.00 \mathrm{a}$ & $12.30 \pm 3.26 \mathrm{~b}$ \\
& 12 & $3.50 \pm 1.50 \mathrm{a}$ & $22.90 \pm 11.35 \mathrm{a}$ \\
Positive control & 0 & $3.50 \pm 1.50 \mathrm{a}$ & $4.36 \pm 1.72 \mathrm{c}$ \\
Negative control & 0 & $110.00 \pm 10.00 \mathrm{~b}$ & $81.18 \pm 1.15 \mathrm{~d}$
\end{tabular}

Means with different superscripts in each column are significantly different $(p<0.05)$ by Tukey's test

recorded highest mortality of $100 \%$ at $8 \%$ concentration in week 1 , and then, its potency declines with time up to the week 4 until no mortality was recorded from weeks $5-8$. Nevertheless, the rate of progeny emergence was significantly low as the weight loss at the end of the experiment was moderately high compared to the negative control. Production of frass started from week 3 post treatment at $8 \%$ and $12 \%$ concentration of P. guineense and $C$. frutescens extracts as a result of unhindered voracious feeding habit of the insects. The observed low progeny emergence of $D$. maculatus treated with $D$. tripetala and C. frutescens could not only be due to high mortality of the larvae but also the anti-feedant property of the extracts. Odeyemi, Owoade, and Akinkurolere (2000) had suggested that cases of high mortality reported in the larvae were partly because of their inability to detoxify plant toxins during feeding activity, especially at 1st-4th larval stage. Credland (1992) reported that the mode of action of plant oils include physical barrier to respiration of insects, eggs and young larvae toxicity, and repellence by constituents. The above observations are in agreement with the studies of Akinwumi (2011); Asawalam, Emosairue, Ekeleme, and Wokocha (2007); Aslam, Ali Khan, and Bajwa (2002); Echezona (2006); Mahdian and Rahman (2008); Nadra (2004); Okonkwo and Okoye (1996); Olayinka-Olagunju (2014); and Owoade (2008).

The positive control in this study exhibited a significant level of protective and preservative potential by recording 67\% mortality in week 1 and later declined in potency to $33 \%$ in week 4 after which no sign of insecticidal activity was seen compared to the negative control which is in agreement with Golob and Webley (1980) which reported that vegetable oils, particularly groundnut and palm oils, are known to be effective in controlling some pests of stored pulses. Don-pedro (1989) also reported that applying vegetable oil and shark liver oil at the rate of $56 \mathrm{ml} / \mathrm{kg}$ and $112 \mathrm{ml} / \mathrm{kg}$ on D. maculatus effectively reduced progeny production. Likewise, Don-pedro (1989) reported that administration of vegetable oil at the rate of $14 \mathrm{ml} / \mathrm{kg}$ on cowpeas resulted in $3 \%$ egg hatchability compared to $76 \%$ on the untreated controls. Haghtalab, Shayesteh, and Aramideh (2009) and Pacheco et al. (1995) reported inhibited population growth and recorded $80.83 \%$ and $86 \%$ mortalities of Callosobruchus maculatus on cowpea when treated with hazelnut oil and castor oil and soybean and crude castor oil, respectively, which is in agreement with the present study. The mode of action of oils is yet to be confirmed but Don-Pedro (1989) suggested that insect death caused by oils is due to anoxia or interference in normal respiration resulting in suffocation. Also Obeng-ofori (1995) stated that oils could act as anti-feedants or modify the storage micro-environment, thereby discouraging insect penetration and feeding. Weaver and Subramanyam (2000) also noted that oils can act as insect growth regulators (IRGs) by affecting metamorphosis.

\section{Conclusion}

The overall results imply that ethanolic extract of $P$. guineense, $D$. tripetala, and $C$. frutescens was only able to protect the smoked fish maximally for 30 days at all concentrations as also observed in the positive control. Highest potency of the extracts was recorded at $8 \%$ concentration for both $P$. guineense and C. frutescens, and $12 \%$ concentration for $D$. tripetala. These explain the high significant weight loss and number of progenies produced by the extracts of $P$. guineense and C. frutescens. However, extract of $D$. tripetala act as an anti-feedant by deterring the larvae from feeding resulting in a number of moribund larvae. This accounted for the negligible weight loss and progeny recorded in both treatments.

The effectiveness of Dennettia tripetala in reducing damage done, progeny emergence, and overall control of $D$. maculatus infestation in smoked fish during storage was exceptional and could serve as a possible means of ensuring a steady supply of good quality smoked fish as against Capsicum frutecsens and Piper guineense which were also effective but not as the former. It can therefore serve as an affordable substitute for synthetic chemicals which had been proven to be detrimental to the health of its consumers because often times smoked fish may be eaten as snacks without washing or further cooking. This study also proved that polishing smoked fish with vegetable oil as commonly done by fish merchants in Nigeria conferred some kind of protection against $D$. maculatus infestation.

\section{Recommendation}

There is however the need for repeated application of the extracts and vegetable oil in order to achieve full protection of stock as being proved in this present study that the insecticidal strength decreases with the length of storage. Further studies are hereby advocated for, as to investigate whether or not higher dosages of these extracts could confer longer protection on smoked fish from $D$. maculatus infestation. 


\section{Abbreviations}

C. frutescens: Capsicum frutescens; D. maculatus: Dermestes maculatus; $D$. tripetala: Dennettia tripetala; P. guineense: Piper guineense

\section{Acknowledgements}

Not applicable

\section{Funding}

Personally funded

\section{Availability of data and materials}

All data generated or analyzed during this study are included in this published article

\section{Author's contributions}

The final manuscript was read and approved by the author.

Ethics approval and consent to participate

Not applicable

\section{Consent for publication}

Not applicable

\section{Competing interests}

The author declares that he has no competing interests.

\section{Publisher's Note}

Springer Nature remains neutral with regard to jurisdictional claims in published maps and institutional affiliations.

Received: 30 October 2018 Accepted: 16 January 2019

Published online: 06 February 2019

\section{References}

Adedire, C. O., \& Lajide, L. (2000). Effects of pulverized plant materials on fish damage and growth performance of the fish beetle (Dermestes maculatus Degeer). Entomological Society Nigeria Occasional Publication, 32, 215-221.

Akinbuluma, M. D., Adepetun, M. T., \& Yeye, E. O. (2015). Insecticidal effects of Capsicum frutescens and Dennettia tripetala against Sitophilus zeamais Motschulsky on stored maize. International Journal of Research in Agriculture and Forestry, 2(11), 1-7.

Akinwumi, F. A., Adedire, C. O. and Fasakin, E. A. 2006. Effect of four plant materials on Egg hatchability of Dermestes maculatus and Necrobia rufipes on smoked African mud catfish Clarias gariepinus, Burchell. Science Research Annals, 21: 38-42.

Akinwumi, F. O. (2011). Evaluation of some plant materials for the control of smoked fish pest, Dermestes maculatus Degeer (Coleoptera: Dermestidae) in Clarias gariepinus Burchell (Pisces: Clariidae). ARPN Journal of Agricultural and Biological Science, 6(7), 65-69.

Anyaele, O. O., \& Amusan, A. A. S. (2003). Toxicity of hexanolic extract of D. Tripetala on larvae of Aedes aegypti. African Journal of Biomedical Research, 6(10), 49-53.

Asawalam, E. F., Emosairue, S. O., Ekeleme, F., \& Wokocha, R. C. (2007). Insecticidal effect of powdered parts of eight Nigeria plants species against maize weevil Sitophilus zeamis Motschulsky (Coleoptera: Curculinidae). Electronic Journal of Environmental Agricultural and Food Chemistry, 6(1), 2526-2533.

Aslam, M., Ali Khan, K., \& Bajwa, M. Z. H. (2002). Potency of some spices against Callosobruchus chinensis L. Online Journal of Biological Sciences, 2(7), 449-452.

Credland, P. F. (1992). The structure of bruchid egg may explain the ovicidal effect of oil. Journal of Stored Products Research, 28, 1-9.

Don-Pedro, K. N. (1989). Mode of action of fixed oils against eggs of Callosobruchus maculatus (F.). Pesticide Science, 26, 107-115.

Echezona, B. C. (2006). Selection of pepper cultivars (Capsicum spp.) for the control of bruchids Callosobruchus maculatus (F.) on stored cowpea (Vigna unguiculata (L.) Walp.) seeds. African Journal of Biotechnology, 5(8), 624-628 Available in: http://www.academicjournals.org/AJB.

Echo, I. A., Osuagwu, A. N., Agbor, R. B., Okpako, E. C., \& Ekanem, B. E. (2012). Phytochemical composition of Aframomum melegueta and Piper guineense seeds. World Journal of Applied Environmental Chemitry, 2(1), 17-21.

Food and Agriculture Organization (1981). The prevention of losses in cured fish. Fisheries technical paper, no. 219, (p. 87). Italy: FAO ROME.
Golob, P., \& Webley, D. J. (1980). The use of plants and minerals as traditional protectants of stored products. In Tropical Products institute, Report G138, England, (p. 32).

Haghtalab, N., Shayesteh, N., \& Aramideh, S. (2009). Insecticidal efficacy of castor and hazelnut oils in stored cowpea against Callosobruchus maculatus (F.) (Coleoptera: Bruchidae). Journal of Biological Sciences, 9(2), 175-179.

Johnson, C., \& Esser, J. (2000). A review of insect infestation of traditionally cured fish in the tropics, (p. 92). London: Department for International Development.

Mahdian, S. H. A., \& Rahman, M. K. (2008). Insecticidal effect of some spices on Callosobruchus maculatus (Fabricius) in black gram seeds. University Journal of Zoology, Rajshahi University, 27, 47-50.

Nadra, H. A. M. (2004). Testing some various botanical powders for protection of wheat grain against Trogoderma granarium Everts. Journal of Biological Sciences, 4(5), 592-597.

Obeng-Ofori, D. (1995). Plant oils as grain protectants against infestations of Cryptolestes pusillus and Rhyzopertha dominica in stored grain. Entomologia Experimentalis et Applicata, 77, 133-139.

Odeyemi, O. O., Owoade, R. A., \& Akinkurolere, R. (2000). Toxicity and population suppression effects of Parkiaclap pertoniana on dried fish pests (Dermestes maculatus and Necrobia rufipes). Global Journal of Pure and Applied Sciences, 6(2), 191-195.

Okonkwo, E. U., \& Okoye, W. I. (1996). The efficacy of four seed powders and the essential oils as protectants of cowpea and maize grains against infestation by Callosobruchus maculatus (Fab) (Coleoptera: Curculionidae) in Nigeria. International Journal of Pest Management, 42(3), 143-146.

Olayinka-Olagunju (2014). Effects of two eco-friendly insecticides (Dennettia tripetala and Piper guineense) against Dermestes maculatus (Degeer) on smoked dried Clarias gariepinus (Pisces: Clariidae). IOSR Journal of Environmental Science, Toxicology and Food Technology (IOSR-JESTFT), 8(7), 37-43.

Owoade, R. A. (2008). Mortality, growth and development of Dermestes maculatus. African scientist, 9, 1.

Pacheco, I. A., de Castro, M. F. P., de Paula, D. C., Lourençao, A. L., Bolonhezi, S., \& Barbieri, M. K. (1995). Efficacy of soybean and castor oils in control of Callosobruchus maculatus (F.) and Callosobruchus phaseoli (Gyllenhal) in stored chickpeas (Cicer arietinum L.). Journal of Stored Products Research, 31, 221-228.

Sowumi, A. A. (2007). Fin-fishes in Yoruba natural healing practices from Southwest Nigeria. Journal of Ethnopharmacology, 113, 72-78.

Weaver, D. K., \& Subramanyam, B. (2000). Botanicals. In Alternatives to pesticides in subtropics, (3rd ed., p. 188). Germany: Margraf Publishers.

\section{Submit your manuscript to a SpringerOpen ${ }^{\circ}$ journal and benefit from:}

- Convenient online submission

- Rigorous peer review

- Open access: articles freely available online

High visibility within the field

- Retaining the copyright to your article

Submit your next manuscript at $\boldsymbol{\nabla}$ springeropen.com 